\title{
Horizontal Inequalities, Political Environment, and Civil Conflict Evidence from 55 Developing Countries, 1986-2003*
}

\author{
Gudrun Østby**
}

\section{Technical Abstract}

This paper investigates the relationship between socioeconomic horizontal inequalities (inequalities between identity groups), regime type, electoral system, political exclusion of minorities and civil conflict onset. A positive link between horizontal inequalities (HIs) and violent conflict has been established by some preliminary empirical studies, but no systematic large-N study has to date investigated whether and how the political environment can affect this relationship. Using Demographic and Health Surveys from 55 developing countries in the period 1986-2003, I calculate welfare inequalities between ethnic, religious, and regional groups based on indicators such as household assets and educational levels. All the HI measures are positively associated with conflict, but the effects seem to be most robust when using the regional group identifier. The regional HI measures are interacted with terms for regime type; electoral system and political exclusion. The results show that the conflict potential of regional HIs is stronger for democracies and semi-democracies than for autocracies. Institutional arrangements also seem to matter since the positive effect of socioeconomic HIs on civil war increases with the level of inclusiveness of the electoral system. Furthermore, the interaction between political exclusion and socioeconomic regional HIs seems to make countries particularly at risk for conflict. This suggests that what is required to secure peace in developing countries is the combination of politically and economically inclusive government. 


\section{Non-Technical Abstract}

Several studies of civil war have concluded that economic inequality between individuals does not increase the risk of internal armed conflict. This is perhaps not so surprising. Even though an individual may feel frustrated if he is poor compared to other individuals in society, he will not start a rebellion on his own. Civil wars are organized group conflicts, not a matter of individuals randomly committing violence against each other. Hence, we should not neglect the group aspect of human well-being and conflict. Systematic inequalities that coincide with ethnic, religious or geographical cleavages in a country are often referred to as horizontal inequalities (or inter-group inequalities). Case studies of particular countries as well as some statistical studies have found that such inequalities between identity groups tend to be associated with a higher risk of internal conflict. However, the emergence of violent group mobilization in a country with sharp horizontal inequalities may depend on the characteristics of the political regime. For example, in an autocracy, grievances that stem from group inequalities are likely to be large and frequent but state repression may prevent them from being openly expressed. This paper investigates the relationship between horizontal inequalities, political environment, and civil war in developing countries. Based on national survey data from 55 countries I calculate welfare inequalities between ethnic, religious, and regional groups for each country using indicators such as household assets and educational levels. All the inequality measures, but particularly regional inequality, are positively associated with higher risks of conflict outbreak. Furthermore, it seems that the conflict potential of regional inequality is stronger for pure democratic and intermediate regimes than for pure autocratic regimes. Institutional arrangements also seem to matter. In fact it seems that the conflict potential of horizontal inequalities increases with more inclusive electoral systems. Finally, the presence of both regional inequalities and political exclusion of minority groups seems to make countries particularly at risk of conflict. The main policyimplication of these findings is that the combination of politically and economically inclusive government is required to secure peace in developing countries.

World Bank Policy Research Working Paper 4193, April 2007

The Post-Conflict Transitions Working Paper Series disseminates the findings of work in progress to encourage the exchange of ideas about post-conflict development (more information about the Post-Conflict Transitions Project can be found at http://econ.worldbank.org/programs/conflict ). An objective of the series is to get the findings 
out quickly, even if the presentations are less than fully polished. The papers carry the names of the authors and should be cited accordingly. The findings, interpretations, and conclusions expressed in these papers are entirely those of the authors. They do not necessarily represent the views of the World Bank, its Executive Directors, or the countries they represent. Policy Research Working Papers are available online at http://econ.worldbank.org .

* Author's Note: Earlier versions of this paper were presented to the PIDDCP (Political Institutions, Development and a Domestic Civil Peace) Workshop in Oxford, 10-12 November, 2005; the National Conference on Political Science, Bergen, Norway, 4-6 January 2006, and at CRISE (Centre for Research on Inequality, Human Security and Ethnicity), Oxford, 24 January 2006. The comments made by participants on these occasions have been most fruitful. I am particularly indebted to Scott Gates, Håvard Hegre, Luca Mancini, Eric Neumayer, Frances Stewart, Håvard Strand and Martha Reynal-Querol for many insightful comments and suggestions. Results, claims and remaining errors are solely my responsibility.

**Gudrun Østby is a PhD Candidate at Department of Political Science, University of Oslo, and a Researcher at the Centre for the Study of Civil War (CSCW), International Peace Research Institute in Oslo (PRIO), Hausmanns gate 7, NO-0186 Oslo, Norway, gudrun@ prio.no, Tel: +47 22857642. 


\section{Introduction}

This paper addresses the interplay between socioeconomic and identity-related factors in civil conflict, guided by a comprehensive approach to organized group conflict, which has been brought to the fore by Stewart $(2000 ; 2002)$ as the concept of horizontal inequalities (HIs). ${ }^{1}$ In brief, the argument is that inequalities that coincide with identity cleavages (such as ethnicity, religion or regional affiliation) may enhance group grievances and thus facilitate mobilization for conflict. In a series of case studies Stewart (2002) found that various dimensions of HIs provoked some kind of conflict, ranging from a high level of criminality in Brazil to civil war in Uganda and Sri Lanka. In order to test whether these findings can be generalized beyond the particular case studies there is a need for large-N investigations. Drawing on national survey data, Østby (2005a) has provided quantitative evidence that Stewart's findings hold when socioeconomic inequalities between ethnic groups are tested systematically across 33 developing countries. She also found similar effects for horizontal inequalities at the regional level with a much larger sample (Østby, 2005b), whereas Brown (2005) reports statistical evidence for a positive effect on conflict of horizontal inequalities between religious groups.

An important issue that has not been systematically addressed to date is whether horizontal inequalities are especially conflict-provoking under certain political conditions. To my knowledge, there has been little systematic theorization of the role of political institutions (such as regime type, and electoral system) in ameliorating (or exacerbating) the conflict potential of horizontal inequalities. This paper examines the independent and interactive effects of socioeconomic horizontal inequalities and regime type, electoral system, as well as actual political exclusion of minority groups. I put forth specific hypotheses as to how the political environment interacts with socioeconomic horizontal inequalities. For instance, I expect that horizontal inequalities may be particularly explosive in democratic and semi-democratic regimes because the relatively deprived groups have both a strong motive and the opportunity for violent mobilization. In order to test these hypotheses I conduct a large-N analysis of civil conflict in up to $55^{2}$ developing countries in the period 1986-2003.

The paper is organized as follows: Section 2 provides a theoretical framework for the relationship between horizontal inequalities and conflict, with a special focus on three different group identifiers: ethnicity, religion, and regional affinity. Section 3 discusses the possible impact of regime type, electoral system, and political exclusion of minority groups in mitigating

\footnotetext{
${ }^{1}$ Horizontal inequality should be distinguished from 'vertical' inequality, which measures inequality between individuals in a society, regardless of ethnic affiliation or other group characteristics of the population. Recent large-N contributions of civil war (e.g Collier \& Hoeffler, 2004; Fearon \& Laitin, 2003) tend to dismiss inequality as a grievance factor, based on such a vertical measure of inequality, hence ignoring the impact of HIs.

${ }^{2}$ Although the DHS surveys allow me to calculate HIs for 61 countries, 6 of these disappeared from the regression analysis either because there was a conflict going on during the entire period 1986-2003 implying that all conflict years were deleted, or due to missing observations on certain of the other variables in the analysis for the entire period 1986-2003 (India; Myanmar; Liberia; Philippines; Sudan and Turkey)
} 
the nexus between socioeconomic horizontal inequalities and conflict. Section 4 presents the data and research design. Section 5 provides the results from the empirical tests. The terms of socioeconomic HIs show a positive effect on conflict onset for both the welfare indicators (household assets and education levels), and across all the three group identifiers (ethnic, religious and regional). Moreover, the results indicate that this effect is influenced by regime type. The conflict potential of HIs seems to be stronger in democracies and semi-democracies than in autocracies. I also find some evidence that not only the level of democracy, but also the institutional setup within the democracies may be of importance here. Although the results are not very robust across various indicators of social welfare (household assets and education), the trend seems to be that the positive effect of socioeconomic horizontal inequalities on civil war increases with the level of inclusiveness of the electoral system. Finally, although direct political exclusion shows no separate effect on conflict, it seems strongly to enforce the positive relationship between regional HIs and conflict. The last section concludes.

\section{Horizontal Inequalities and Civil Conflict}

Stewart (2002: 1) defines horizontal inequalities as 'systematic inequalities between culturally formed groups', such as ethnic, religious or regional groups. Systematic, socioeconomic inequalities between identity groups often have their origin in historical circumstances, such as colonial policies, which privileged some groups over others. Sometimes, however, horizontal inequalities are not caused by deliberate agency at all but simply become evident for example when traditional peoples on the periphery of modernizing societies are drawn into closer contact with more powerful and technologically proficient groups (Gurr, 2000). ${ }^{3}$ An initial advantage often leads to long-term cumulative advantages, as resources and education allow the more privileged groups to secure further advantages. Likewise, group deprivation tends to be reproduced over time, like in South Africa - even after apartheid (see e.g. World Bank, 2006: 1).

A shared cultural identity may be a powerful organizing principle for a group. First of all, it overcomes the collective action problem (Olson, 1965) whereby people are unable to cooperate because of mutual suspicions. However, there is reason to believe that a shared identity is not a sufficient factor to produce conflict. In line with this, Murshed \& Gates (2005) argue that some well-defined grievances are required for identity-based conflict.

Given that groups are the central units in conflicts the question then is how they are mobilized. Stewart (2000) shows how different identity bases have been the source of group differentiation and mobilization: In central Africa, ethnicity has been the major basis of group categorization; in Central America, group identification and organization has developed along social class lines, with some overlapping ethnic dimensions; and in the Balkans and Northern Ireland religion has been the primary feature of categorization. However, regional location is a source of group differentiation, which often coincides with ethnic or linguistic cleavages, like for

\footnotetext{
${ }^{3}$ Without analyzing each country in depth it is hard to tell whether group inequalities predate repression or not. Furthermore, objective measures of group inequalities do not necessarily perfectly reflect people's perceptions of such inequalities. An ongoing project at Centre for Research on Inequality Ethnicity and Human Security (CRISE) at the University of Oxford, involves mapping people's perceptions of group inequalities in eight countries based on particular perception surveys. This seems as a promising start for studying the degree to which people's grievances correspond with objective group inequalities in society.
} 
example in Uganda (Minority Rights Group International, 1997) and Zambia (Posner, 2004). The question of regional, or spatial, inequality has become increasingly important over recent years, and has begun to attract significant interest among scholars and policy-makers. In most developing countries, there is a sense that regional inequalities within countries in terms of economic activities and social indicators are rising (Kanbur \& Venables, 2005).

Stewart $(2000 ; 2002)$ does not explicitly specify what kind of cultural identifier is most relevant for conflict, but proposes that one can often use regional data to proxy differences among ethnicities since regional location tends to coincide with ethnic or language divisions (Stewart, 2000: 247, 255). Moreover, data on group inequalities are far more accessible for regional than ethnic or religious groups, since questions concerning ethnic affiliation are often dropped or at least not published in national surveys and censuses. However, regional groups may also be important in their own right: In a natural field experiment among the Chewa and Tumbuka groups in Zambia Posner (2004: 543) found that the regional cohesion seemed to be stronger than the claims of ethnic affiliation: ${ }^{4}$

'Whether or not a cleavage matters would seem to depend not at all on the material from which it is built. That material can be as sturdy as the traits, customs, norms, and practices that a professional ethnographer might identify as flimsy as an arbitrary boundary drawn by an uninformed colonial officer'.

In general, why should horizontal inequalities be relevant for conflict? The most obvious answer to this question relates to the effect of collective grievances. Members of disadvantaged groups are likely to feel frustration and antagonism, especially when their relative deprivation is the result of actual exploitation and discrimination, which is apparently often the case (for example in Senegal and Uganda). Indeed, Horowitz (2000) holds that in most cases conflicts are initiated by the less privileged groups. Despite the intuitive logic of this argument, one cannot, however, assume that it is only resentment on the part of the disadvantaged groups that may cause political instability. The privileged groups may also attack the unprivileged, fearing that the latter may demand more resources and political power (Stweart, 2000). According to Tadjoeddin (2003) this is actually what happened in Indonesia, where conflicts often stem from confrontations between the central authorities and several richer provinces (in terms of natural resources) whose people are upset by the center's use of their region's wealth to subsidize poorer regions.

When people in rich regions perceive the central government's policies as unfair and authoritarian, they may see greater autonomy, or even secession, as a better alternative than the status quo. As Aristotle said, 'Inferiors revolt in order that they may be equal, and equals that they may be superior' (quoted in Sigelman \& Simpson, 1977: 106). For example, privileged groups that are geographically concentrated may demand independence, such as the Basques in Spain. In line with this logic, the initiative to conflict may come from the richest and most privileged groups as well as the poorest and most deprived groups. Both types of reactions point to the conclusion that a society of high horizontal inequalities has a higher risk of civil war than societies without such inequalities. It is easier to maintain group cohesiveness and motivation for rebellion if the elite can draw on ethnic, religious, or regional differences to construct a well-

\footnotetext{
${ }^{4}$ Nevertheless, it should not be ignored that some of the worst forms of ethnic attacks have been non-regional, such as the conflict between Hutus and Tutsis in Rwanda.
} 
defined identity group with a common enemy. However, probably what matters more than the identity bases between which the cleavage is created is whether the groups are systematically different in terms of economic and social welfare. This leads to my first hypothesis:

H1: Countries with severe socioeconomic horizontal inequalities are particularly likely to experience civil conflicts, ceteris paribus.

\section{Mediating Effects of the Political Environment on the HI- Conflict Nexus}

Rogowski \& MacRae (2004), among others, have demonstrated that political institutions tend to co-vary with socioeconomic inequality in society. For example, societies with clientelistic politics are often associated with extreme economic inequality ${ }^{5}$, and democracies are characterized by greater economic equality between rich and poor than autocracies. Even within the set of democratic regimes, institutions and inequality seem to correlate. Countries with majoritarian electoral institutions, for example, display greater economic inequality than countries with proportional methods of election (PR).

The bulk of studies on inequality and institutions focus on inequality between individuals. One could expect, however, that the findings presented above also hold for the relationship between institutions and group-based inequalities. Alternatively, one could argue that requirements for plurality would force coalitions of identity groups and hence mitigate horizontal inequalities. ${ }^{6}$ However, establishing a causal link between horizontal inequalities and political institutions is beyond the scope of this paper. Rather, its focus lies in investigating how the political environment in a country may influence the relationship between horizontal inequalities and civil conflict onset.

\subsection{The Impact of Democracy Level}

According to Rothchild (1983) 'group disparities and unequal exchange are, in and of themselves, insufficient to explain the course of interethnic conflict'. Stewart (2000: 11) argues that the sheer existence of horizontal inequalities may not spur conflict 'if there is a strong state which suppresses it or if ideological elements are such that the inequalities are not widely perceived'. If this is the case, the emergence of violent group mobilization in countries with sharp HIs may depend on the characteristics of the political regime.

The relationship between regime type and civil conflict has been widely studied. Hegre et al. (2001) have demonstrated an inverse U-shaped relation between the level of democracy and the incidence of civil war over time, concluding that semi-democracies are indeed the most prone to civil strife. At both extremes, in autocracies and democracies, civil wars are rare - and even rarer under a democracy than under an autocracy. However, in a semi democracy, they argue, the combination of both grievances and the opportunity to rebel is at its peak. In a democracy

\footnotetext{
${ }^{5}$ It might also be the case that clientelism is very widespread in early stages of development.

${ }^{6}$ One should also note a possible reverse causality, implying that political inequalities might lead to economic inequalities.
} 
grievances are generally rare and more moderate while there are plenty of possibilities to express these grievances and to secure change through channels other than violence. In an autocracy, on the other hand, grievances are likely to be large and frequent but state repression may prevent them from being openly expressed. In a semi democracy, both grievances and opportunities exist for violent conflict. This suggests that state failure is more likely in between autocracy and wellfunctioning democracy.

The first interaction I investigate in this paper is that between horizontal inequalities and regime type. Regime characteristics may provide the incentives for deprived groups to riot against the government, as autocratic regimes are likely to have a very restricted recruitment process both for political and economic positions (Goldstone, 2001). Autocracies have a tendency to exacerbate inequality (Rogowski \& MacRae, 2004). Consequently, one could reason that when horizontal inequalities are pervasive, autocracies are likely to be more at risk of conflict than democracies. This paper turns this reasoning upside-down arguing that it is rather democratic regimes that suffer from the most serious effects of horizontal inequalities. The rationale for this is elaborated below.

The theory of the democratic peace makes a heroic assumption: that democracies are actually responsive and do address group grievances. Intuitively, this makes perfect sense. Democracies are by definition expected to be more responsive than autocracies, if for no other reason than that they usually entertain a free press, which makes it harder to ignore petitions from below and because governments can be voted out. However, being more responsive than an ideal autocracy is not sufficient to argue that a democracy is able to avoid all potential conflicts. ${ }^{7}$ If, for various reasons, a democracy is unable to secure universally basic satisfaction and ensure a certain level of group equity, a whole set of new dynamics may appear. The opportunity to rebel is still present, but it is now combined with the presence of strong group grievances, or motives. In other words, in a country with both a suppressive regime and persistent horizontal inequalities, there will be very little opportunity to mobilize although grievances among the disadvantaged groups are likely to be very strong indeed. In a democracy with sharp horizontal inequalities on the other hand, opportunities and grievances are both present. A democracy is, however, expected to host moderate inequalities and consequently fewer grievances between identity groups. This is due to the existence of several peaceful channels through which relatively deprived groups may express and voice their potential grievances and try to influence the process of redistribution through democratic means. However, if this effort does not reduce the growing gap between the expected and the actual outcome for the relatively disadvantaged groups, it may cause frustration and facilitate the mobilization of people to engage in conflict. This argument was originally expressed by Davies (1962) as the J-curve of need satisfaction and revolution. In line with this reasoning one should expect the most conflict prone societies to be democracies with sharp horizontal inequalities. Hence, I propose the following hypothesis:

$\mathrm{H} 2$ : The positive effect of socioeconomic horizontal inequalities on civil conflict onset is stronger for democracies and semi-democracies than for autocracies, ceteris paribus.

\footnotetext{
${ }^{7}$ This fits with some of the findings in Aydin \& Gates' (2005) work on genocide. They provide empirical evidence of an inverse relationship between decision-making constraints in policymaking and leaders' incentive to target civilians. The level of political participation and openness of executive recruitment are however not associated with geno-/politicide.
} 
With regard to $\mathrm{H} 2$, it should be noted that by 'semi democracies' I here refer to regimes which are neither fully democratic nor fully autocratic. However, such regimes are often also transitional polities. Political change is complicated, and democratization can be marked by increased risk of internal conflict (Hegre et al., 2001). For example, voting may threaten the power of particular groups, which may use violence during elections or immediately postelection. This may be so because, while willing to accept democratic institutions in principle, these groups may not be willing to accept the transfer of power that is involved. ${ }^{8}$ In line with this, Horowitz (1993) found that political change is particularly likely to be accompanied by civil conflict in countries with different ethnic minorities.

Hegre et al. (2001: 33) conclude that 'intermediate regimes', or semi democracies, are most prone to civil war, even when they have had time to stabilize from a regime change. However, the authors also note that in order to assess whether intermediate regime or regime transition (or both) are significant, one needs to control for each factor. Following this advice, I control for the time since regime change when testing $\mathrm{H} 2$.

\subsection{The Impact of the Electoral System}

Political inclusion of minority groups is necessary to avoid the monopolization of political power by one ethnic group or another. Inclusion, however, does not follow automatically from all forms of democratic institutions (Rogowski \& MacRae, 2004). Hence, I also consider the impact of a country's level of political inclusiveness, proxied by its electoral system. Reynal-Querol (2002a,b) shows that what matters for conflict is not necessarily simply the degree of political freedom (or democracy), but rather the combination of this and the system of representation of the voters in government. More specifically, she found that proportional systems have a lower risk of conflict than majoritarian systems. Her explanation of this result is that the opportunity cost of rebellion is higher under proportional systems because such systems are likely to be more inclusive and curb grievances. It could also be the case that the lower risk of conflict in proportional systems is simply due to the fact that these systems are likely to be more inclusive and hence curb grievances. Reynal-Querol's results corroborate with Binningsbø (2005), who in a large-N study of 118 post conflict societies between 1985 and 2002 found that power-sharing institutions as recommended by Lijphart (e.g. 1999), notably proportional representation systems and territorial autonomy, were positively associated with lasting peace. Despite such findings, Lijphart's theory about consociational democracy in plural societies has also been met with scepticism. ${ }^{9}$ For example, van den Berghe (2002) argues that the institutional model of consociational democracy mostly benefits the ruling elites. ${ }^{10}$ Furthermore, Horowitz (2000) has criticized Lijphart on the grounds that the heterogeneous countries in Europe which form the basis of Lijphart's theory are not sufficiently comparable to deeply divided countries in Africa and Asia. In fact, Horowitz argues that a proportional representation system does not necessarily

\footnotetext{
${ }^{8}$ Thanks to Frances Stewart for raising this point.

${ }^{9}$ See Binningsbø (2005: 11-12) for an overview of this critique.

${ }^{10}$ However, this could be true and yet also be pro-peace.
} 
create compromise or moderate attitudes, but may actually fuel such differences, as it can encourage ethnic or religious political parties. ${ }^{11}$ Lebanon might be a good example of this.

Based on case studies of Kenya, Uganda, and Sri Lanka, Stewart \& O’Sullivan (1998) argue that democratic institutions are not sufficient to prevent conflict in strongly divided societies, and that redesigning democratic institutions in order to reduce conflict can fail to do so, or even accentuate it, as in Sri Lanka. They conclude that in order to prevent conflict there is a need for inclusive government - politically as well as economically. This entails not only political participation by all major groups, but also a spread of the economic benefits throughout society.

In countries with strong socioeconomic horizontal inequalities, but yet a high level of political inclusiveness, Stewart \& O'Sullivan (1998) note that political parties and leaders tend to accentuate ethnic divisions in order to gain support by their kinsmen. This in turn can provoke violence. Also, it is my argument that the levels of frustration among the economically relatively deprived will be particularly high in democracies with highly inclusive electoral systems which despite this institutional arrangement fail to even out, or at least reduce, systematic socioeconomic inequalities between identity groups. Hence, I expect that:

H3: The conflict potential of socioeconomic horizontal inequalities increases with more inclusive electoral systems, ceteris paribus.

\subsection{The Impact of Political Exclusion of Minorities}

Regime type and formal political institutions, such as the electoral system, do not necessarily reflect the distributional politics in a society. ${ }^{12}$ Furthermore, there are examples of democratic countries which nonetheless restrict the political participation of certain minority groups, notably several Latin American countries. According to Stewart (2000), consistent horizontal inequalities over a number of dimensions may be as relevant to conflict as the actual coefficient of variation with respect to any one dimension. Can one expect more negative consequences where HIs are inconsistent across dimensions (e.g. where one group is favoured in terms of economic assets, but relatively deprived concerning access to the political system) than where they are consistent? Stewart (2000) holds that countries in which horizontal inequalities are consistent across different dimensions of inequality have a greater risk of conflict than countries in which horizontal inequalities are nonexistent or inconsistent.

Langer (2005) further develops this argument in a study of violent group mobilization and conflict in Côte d'Ivoire. He focuses on socioeconomic horizontal inequalities at the mass level and political horizontal inequalities at the elite level, arguing that the simultaneous presence of these phenomena can be especially explosive for two reasons: First, in such situations the excluded political elites have strong incentives to mobilize their supporters for violent conflict

\footnotetext{
${ }^{11}$ See also Wilkinson (2004), who found that systems with an intermediate number of political parties are more prone to ethnic conflict than systems with two or more than four parties. If this is the case it is not necessarily the electoral system as such which matters regarding conflict risk in plural societies

${ }^{12}$ In fact, the correlation between regime type and political discrimination is -.09 in my dataset.
} 
along group lines, and secondly, with widespread socioeconomic inequalities, the elites are likely to gain support among their ethnic constituencies quite easily. According to Langer (2005) the absence of political horizontal inequalities among the elites reduces the risk of violent group mobilization, even if there are severe socioeconomic divisions between different ethnic and regional groups within a country, because in such situations group leaders lack the incentives to mobilize their constituents for violent conflict. This paper tests Langer's argument with a crossnational sample. From this follows my final hypothesis:

H4: The conflict potential of socioeconomic horizontal inequalities increases with the level of political exclusion of minority groups in a country, ceteris paribus.

\section{Data and Research Design}

A statistical analysis of onsets of civil conflicts in developing countries serves as the empirical test of the outlined hypotheses. The sample includes all developing countries where at least one Demographic and Health Survey (DHS) had been conducted during the period 1986-2003 and for which the data were available. In total this amounts to 123 national surveys in 61 countries. The total number of observations in the dataset add up to 1160 country-years. However, when consecutive years of conflict are removed from the analysis a maximum of 806 country-years remain.

\subsection{The Dependent Variable: Conflict Onset}

The conflict data are derived from the Uppsala/PRIO Armed Conflict Dataset (ACD), which includes every armed conflict between a state government and an organized opposition group that caused at least 25 battle-related deaths per year (Gleditsch et al., 2002). My definition of conflict applies the 'two-year rule' (see e.g. Buhaug \& Gates, 2002): if a conflict falls below the casualty threshold for at least two consecutive calendar years, the next observation is coded as a separate onset. I merge sub-conflicts that only differ in type (internal vs. internationalized internal conflict), and censor consecutive years of conflict.

\subsection{Core Variables}

The estimates for socioeconomic inequalities within and between regions are based on aggregated data from 123 Demographic and Health Surveys (DHS) conducted in 61 countries during the period 1986-2003. DHS is an ongoing research project which provides data on the population, health, and nutrition of women and children in developing countries, funded primarily by USAID and administered by Macro International Inc. In a DHS survey, a sample of households is selected throughout the entire country and then interviewed using a household questionnaire to collect housing characteristics. Women between the ages 15 and 49 are interviewed by means of a women's questionnaire to collect information mainly on background characteristics, children and women's health and other issues, such as household assets and 
education level. All of the DHS surveys used in this analysis are nationally representative. Table A2 provides a complete list of the surveys (countries and survey years) used in this analysis to generate the HI variables.

\section{Socioeconomic Horizontal Inequalities}

The DHS data provide a rich set of large, representative surveys with nearly identical questionnaires, hence presenting a golden opportunity for generating objective measures of inequalities across identity groups. However, a challenge is that the DHS surveys generally lack information on income or consumption expenditures. I overcome the absence of such data by using the information collected on respondent and household characteristics. More specifically, I use two different indicators of socioeconomic welfare to calculate the inequality measures and evaluate the hypotheses: a household asset index, and a variable counting the years of education for each respondent.

First, I construct a household asset index, generated on the basis of the following variables from the DHS surveys: v119-v125 (dummies for whether or not each household has electricity, a radio, a television, a refrigerator, a bicycle, a motorcycle and/or a car). My second indicator, schooling inequality, is based on the variable v133 (years of education completed).

I measure horizontal inequalities in household assets and educational level using three different group identifiers from the DHS surveys: ethnicity (v131), religion (v130), and region of residence (v101). First I calculate the socioeconomic divisions (HIs) between the two largest ethnic groups in each country. Second I do the same for the two largest religious groups. ${ }^{13}$ Finally, I examine horizontal inequality as ratios of welfare scores between the region in which the capital is located and the rest of the country. ${ }^{14}$ This measure is calculated on the basis of the formula introduced by Østby (2005a):

$$
H I=1-\left(\exp \left(-\left|\ln \left(\sum_{i=1}^{M} \frac{A_{i 1} / A_{i 2}}{M}\right)\right|\right)\right)
$$

where $M$ is the maximum number of household assets; $A_{1}$ refers to mean asset score of group 1 (e.g. the capital region) and $A_{2}$ is the corresponding mean score of group 2 (e.g. the rest of the country). This provides a continuous variable potentially ranging from 0 (the lowest level of asset inequality between capital region and the rest of the country) to 1 (the highest level of such inequality). The measure of educational inequality is generated along the same lines. For countries where multiple surveys have been undertaken, I use linear interpolation to estimate inequalities for the intervening years. Otherwise I copy the results from the survey closest in time to the subsequent years, within the period 1986-2003 in order to increase the sample to a more manageable size. This could imply a problem of endogeneity (i.e. HI could result from former conflict instead of vice versa), and it would of course be preferable to have annual data on group inequalities for each country. However, as stated earlier, group inequalities tend to be quite stable over time, which is also evident from the data for some of the countries which have had several surveys during the period 1986-2003. Figures 1 and 2 depict the level of inequality in

\footnotetext{
${ }^{13}$ The group sizes are based on weighted measures of ethnic and religious groups (see Rutstein \& Rojas (2003) for details on DHS weighing procedures)

${ }^{14}$ The capital is coded based on the CIA World Factbook, various editions.
} 
terms of average household assets and years of education for the capital region and the rest of the country in Peru and Zimbabwe, respectively for various survey years. In both countries the level of inequality has remained relatively stable over the entire period.

\section{Political Regime Type}

I use data on regime type from the Polity IV data (Marshall \& Jaggers, 2003). Like Jaggers \& Gurr (1995) I compute one single regime indicator, subtracting the score of autocracy from that of democracy, ranging from -10 (most autocratic) to 10 (most democratic). In order to test the curvilinear relationship between regime type and civil conflict I include a squared term for regime type. Finally, in order to assess whether horizontal inequalities are more dangerous in certain regime types, I split the polity term into three categories: democracies (6 to 10), semi democracies ( -5 to 5 ), and autocracies ( -10 to -6$)$, following Ellingsen (2000) and others. I include the dummies for semi democracies and autocracies in the analysis, with democracies as the reference category.

In order to test my hypotheses with an alternative operationalization of regime type, I also include the term SIP (which stands for 'Scalar Index of Polities') proposed by Gates et al. (2006). ${ }^{15}$ This measure is the average of the scores on the three dimensions: The first dimension is the regulation of Executive Recruitment, based on three indicators from the Polity IV dataset: 'Regulation of Chief Executive Recruitment' (XRREG), 'Competitiveness of Executive Recruitment' (XRCOMP), and 'Openness of Executive Recruitment' (XROPEN). The second dimension characterizes the constraints on the executive and is based on a single indicator 'Decision Constraints on the Chief Executive' (XCONST) from Polity IV. The third dimension concerns political participation. Rather than using Gurr's participation index, Gates et al. (2006) base their measure on a slightly modified version of the Polity Participation index from Vanhanen's (2000) Polyarchy dataset. The SIP measure ranges from 0 to 1 . Finally, in order to test Hypothesis 2, I include interaction terms multiplying regime type and regional HIs.

\section{Proximity to Regime Transition}

As stated earlier, semi democracies are found to be the most conflict-prone (Ellingsen 2000; Hegre et al. 2001). This category includes both regimes in transition and institutionally inconsistent regimes. In order to control for whether transitions might make up parts of this relationship as opposed to institutionally inconsistent regimes, as suggested by Hegre et al. (2001), I introduce a variable measuring the time since regime transition when evaluating Hypothesis 2. Polity IV includes a variable 'DURABLE' which measures regime durability (i.e. years since regime transition) as a function of the number of years since the most recent regime change (defined by a three-point change in the POLITY score over a period of three years or

\footnotetext{
${ }^{15}$ The SIP measures was proposed by Gates et al. (2006) as an alternative to the POLITY IV measure due to various problems with the political participation dimension of the latter noted by the authors. Most notably, Gates et al. point out that analyses of conflict which use the Polity measure potentially suffer from endogeneity problems because the Polity coding scheme classifies $40 \%$ of all the polities as 'factional' systems, i.e. systems which are particularly likely to be engaged in civil war. See Gates et al. (2006) for more details.
} 
less) or the end of transition period defined by the lack of stable political institutions (denoted by a standardised authority score). Following Hegre et al. (2001), I then code Proximity of Regime Transition as $2^{\wedge}$ (-years since regime transition/X). I chose 1 as the value of $\mathrm{X}$, which assumes that the impact of a regime transition on the probability of domestic armed conflict is initially high and then reduced at a constant rate with a half-life of one year.

\section{Electoral System}

A term measuring the inclusiveness of electoral systems is constructed on the basis of data from Golder's (2005) dataset Democratic Electoral Systems Around the World, 1946-2000. I basically adopt the idea presented in Reynal-Querol (2002a,b), constructing an ordinal variable ranging four dummies with respect to political inclusiveness. However, I base my measure on Golder's definition of the electoral system followed in the assembly and type of the executive: The variable takes the value ' 0 ' if the system is not free (i.e. if it has a POLITY score of -6 or less or is coded as an autocracy by Golder (2005), ' 1 ' if it has a majoritarian system, '2' if it has a mixed system, and ' 3 ' if it has a proportional system. As noted by Reynal-Querol (2002a: 45), the election of a president is by definition by majority rule, hence what can make a difference is the voting rule followed in the assembly. Hence, presidential systems which use a proportional or mixed voting rule in the election of the assembly are coded as ' 2 ' in my variable for inclusive electoral system. Otherwise, they are coded as ' 1 '. Since the codings of electoral and institutional systems are from the end of each year, the variable is lagged one year in order to determine causality. There are about $15 \%$ missing observations. Most of these are due to the fact that the voting data only go to 2000 (or 2001 when lagged). In order to test whether the level of political inclusiveness influences the relationship between horizontal inequality and civil conflict, I also include an interaction term multiplying the political inclusiveness and regional HIs.

\section{Political Exclusion of Minorities}

Drawing on the Discrimination Dataset of the Minorities at Risk (MAR) Project (Davenport, 2003), I include a term for political exclusion of minority groups in a given year. I use the variable POLDIS, which is originally coded for each minority group as an ordinal variable ranging from 0 (no discrimination) to 4 (exclusion/repressive policy: public policies substantially restrict the group's political participation by comparison with other groups). Aggregating this information to the country level I multiply the discrimination index with the population share of the minority discriminated against. In case of several minorities the sum of all population weighted discrimination indices is taken. ${ }^{16}$ For my sample, the new continuous variable ranges from 0 (e.g. Tanzania, various years) to 3.56 (Rwanda, 1994). I also include interaction terms multiplying the political exclusion and regional HIs.

\footnotetext{
${ }^{16}$ See Neumayer (2003) for a similar application of the MAR data with regard to economic group discrimination at the countrylevel.
} 


\subsection{Control Variables and Statistical Model}

Achen's (2002) 'Rule of Three', states that every analysis with more than three variables on the right-hand side will invariably be invalidated by serious problems of multicollinearity. I do not adhere to this rule, but believe that it is wise to keep the control variables at a minimum, especially given the limited sample size under study.

As noted by Hegre \& Sambanis (2005) three core variables are almost always included in models of civil war onset: the natural log of population; the natural log of per capita GDP; and the length of peacetime until the outbreak of a war (i.e. the time since the last conflict). I include these three controls, of which the first is particularly relevant due to potential problems of spuriousness, given that inequality may be related to the actual level of economic development in a society. Data on population size stem from the WDI (World Bank, 2004). The variable is interpolated and log-transformed. To proxy economic development I use log-transformed GDP per Capita measured in constant 1995 US\$, also from the WDI (World Bank, 2004). The variable is lagged one year.

As suggested by Beck, Katz \& Tucker (1998), I control for temporal dependence through a variable measuring time since the last conflict and three cubic splines that approximate the discrete time hazard rates for conflict. Time since the last conflict counts the number of whole years since the end of the last conflict (peace years). The statistical tests were conducted using STATA, version 8.2 (StataCorp., 2003), and all models were estimated by logit regressions with robust standard errors clustered by countries.

\section{Results}

The findings from the empirical tests of theoretical propositions are presented in Tables 1-4. All models include the base variables, i.e. the terms for population size, GDP per capita and controls for conflict history (peace years and cubic splines). To these I add my various terms for horizontal inequalities and interactions of these with the terms for political institutions in order to evaluate Hypotheses 1-4.

\subsection{Do HIs Matter for Conflict across Different Group Identifiers?}

Models 1-6 in Table 1 report the effects of socioeconomic horizontal inequalities (measured in terms of household assets and education years) with regard to conflict onset. I test the impact of HIs between ethnic, religious, and regional groups respectively. As for the control variables the results are inconsistent. I fail to find the positive relationship between population size and conflict reported by most other studies of civil war (see e.g. Collier \& Hoeffler, 2004; Fearon \& Laitin, 2003). In model 1 the effect is in fact negative at the $10 \%$ level, but in Model 2 the effect drops below significance. In Models 3-6 the effect is positive but never reaches significance. Similarly, the term for GDP yields inconclusive results, and is only negative and significant in Models 1 and 2, whereas the sign switches in the rest of the models. However, these results are perhaps not so surprising, given that the sample is restricted to low- and medium-income countries. When I run the baseline model (i.e. excluding any term for HIs) on a more inclusive 
sample (up to 147 countries) for the same period, both the terms for population size and GDP per capita show the expected effects. Furthermore, when I reran the model with the same sample as in Model 6, but no term for HI, the effects of population size and GDP per capita dropped to insignificant levels (see Table A3). Finally, the term for years of peace never reaches significance in any model, but that may be due to the short time-period (1986-2003). ${ }^{17}$

In contrast to the control variables, the horizontal inequality terms reveal some interesting results. My first hypothesis (H1), assuming a higher risk of conflict for countries with severe socioeconomic horizontal inequalities is quite well supported in Table 1. All the terms show positive significant effects. Models 1 and 2 report the effects of HIs between the two largest ethnic groups in a country, Models 3 and 4 report the effects of HIs between the two largest religious groups in each country, and Models 5 and 6 report the effects of HIs between the capital region and the rest of the country. The reason for the differences in $\mathrm{N}$ is the different availability of data. All the DHS surveys include questions regarding regional affiliation, but several surveys exclude questions about ethnic and religious affiliations.

As expected, the term for horizontal asset inequality between ethnic groups shows a positive significant effect in Model 1. Although only significant at the $10 \%$ level, the marginal effect is quite strong. For a country with mean values on all the explanatory factors, the probability of onset of civil conflict in any given year is $2.3 \%$. If we increase the level of horizontal asset inequality to the $95^{\text {th }}$ percentile while maintaining the other variables at their mean, the probability of a conflict onset increases to $6.1 \%{ }^{18}$ The effect for educational HI between ethnic groups (Model 2) is also positive with the probability of conflict increasing to 5.4\% Focusing on HIs between religious rather than ethnic groups in Model 3 and 4, the effects seem quite similar. ${ }^{19}$ Models 5 and 6 both provide strong support for H1, showing that interregional horizontal inequalities increase the risk of conflict both with regard to assets and education level. Both coefficients are positive at the $1 \%$ significance level, and their effects are very similar: If we increase the level of interregional horizontal inequality to the $95^{\text {th }}$ percentile while maintaining the other variables at their mean, the probability of conflict increases from about $3.8 \%$ to $9.5 \% .^{20}$ This finding corresponds well with related investigations, such as Murshed \& Gates (2005) who find that Nepalese districts with severe gaps relative to Kathmandu in terms of schooling are associated with higher conflict intensity.

The data material presented here might be too scarce to convincingly conclude that regional inequalities matter more for conflict than HIs between ethnic or religious groups. However, since there is more data for regional HIs than ethnic or religious HIs, I conduct the rest of the analyses only with the former terms in order to maximize the size of the sample (and number of conflicts) when testing the effects of interactions with the institutional variables.

\footnotetext{
${ }^{17}$ It is always the possibility that conflict history (peaceyears) may be explained by other independent variables. Hence, I also ran all the models 1-19 without the terms for peaceyears and splines (regressions not shown here), but there were no substantial changes in the results.

${ }^{18}$ Marginal effects were calculated with the aid of CLARIFY software in Stata 8.2 (see Tomz et al., 2003).

${ }^{19}$ Increasing the inter-religious $\mathrm{HI}$ term for assets and education respectively, the conflict risk increases from $2.9 \%$ to $7.2 \%$ and $7.1 \%$.

${ }^{20}$ When I ran Models 5 and 6 with the same sample as Model 1 and $2(n=473)$ the results for the inter-regional HI largely hold, although the effects are slightly weaker.
} 
Ideally, we should know which groups are salient with regard to welfare distribution and conflict potential in each society (Stewart, 2000). Some studies measure inequalities between ethnic groups (Østby, 2005a), some focus on inequalities between religious groups (Brown, 2005), whereas others investigate inequalities between regions (Østby, 2005b). One solution could be to calculate group inequalities between all these groups and then simply investigate the conflict potential of the most severe variants of inter-group inequalities in each country. However, there are potential problems with such an approach as well. First of all the reason why some states choose to exclude information about ethnicity and religion, these group factors may be particularly explosive (see Strand \& Urdal, 2005), and hence the missing information on horizontal inequalities between these groups could very well be biased. Nevertheless I calculated such terms of maximum HIs for both asset and educational inequality, and among the three different group-identifiers, HIs between regions is the term that correlates most strongly with the term for maximum HIs: ( $\mathrm{r}=0.93$ for asset $\mathrm{HI}$ and $\mathrm{r}=0.79$ for educational $\mathrm{HI}$ ). The corresponding values for ethnic HIs are 0.63 and 0.25 , and for religious HIs: 0.51 and 0.26 .

\subsection{Are HIs More Likely to Lead to Conflict in Democracies?}

Can we expect the effect of horizontal inequalities to be contingent on regime type as indicated by $\mathrm{H} 2$ ? This hypothesis is tested in Table 2. First of all, the effect of regional asset HI seems to be independent of regime type (Model 7). The positive effect is robust to the inclusion of the dummies for autocracy and semi democracy, but there is no significant interaction effect with either of the terms. However, the hypothesis is supported in Models 9-11, which include the interaction terms of regional educational $\mathrm{HI}$ and the various regime variables. First of all, the positive effect of horizontal educational inequality is significantly weaker for autocracies than for democracies and semi-democracies (Model 9). Although not significantly different from each other the effect also seems to be weaker in semi-democracies than in full-fledged democracies. In sum, horizontal inequalities seem to be less likely to cause conflict in autocracies. Figure 3 visualizes the association between inter-regional educational inequality and the estimated probability of conflict onset for the three different regime types, democracies (solid line), semi-democracies (dashed line) and autocracies (thin line). The figure shows that for relatively low levels of horizontal inequalities (0-0.3) the risk of conflict seems to be lowest for the democracies and highest for the autocracies. However, with increasing levels of horizontal educational inequality the picture changes quite dramatically: A democracy with strong horizontal educational inequality between regions $\left(95^{\text {th }}\right.$ percentile $\left.=0.8\right)$ is in fact about twice as likely (appr. 14\%) to face a conflict onset as an autocracy with the same level of HI (appr. 7\%). ${ }^{21}$ In a semi democracy with severe HIs, the risk of conflict is about $11 \%$, but this is not significantly different from democracies.

The relationships between HIs, regime type and conflict onset also hold when I include the term for proximity to regime change in Model 10, with the coefficients remaining largely

\footnotetext{
${ }^{21}$ Not surprisingly, there are not many examples of countries in my sample which are democracies that host severe inequalities and conflict onset in a given year. One example is the conflict onset in Niger in 1994, corresponding with a lagged polity score of 8 and a HI (education) score of appr. 0.80 .
} 
similar. However, as the model demonstrates, proximity to regime change seems to be strongly and positively associated with conflict for the developing countries in my sample. ${ }^{22}$

Furthermore, Hypothesis 2 gains further support in Models 11 and 12 where I include the two different continuous regime measures, POLITY and SIP. The more democratic the regime, the stronger the positive effect of horizontal inequalities for conflict onset.

\subsection{Is the HI-Conflict Nexus Affected by the Electoral System?}

Having demonstrated that regime type seems to influence the relationship between horizontal inequality (at least when measured in terms of education levels) and civil conflict onset, I continue to address the potential impact of electoral systems, in order to see whether certain unequal democracies are more at risk of conflict than others. In Models 13-16 in Table 3 I test the interaction effects of socioeconomic inequalities between regions and the level of political inclusiveness. Again, both the terms for HI remain strongly positively significant regardless of the inclusion of the term for political inclusiveness. The single effect of the latter is negative, indicating that conflict risk decreases with increased levels of political inclusiveness, but this effect is not significant even at the $10 \%$ level. Although with a positive sign, the interaction effect of asset HI and political inclusiveness is not significant, as shown in Model 13. However, the effect of educational HIs, is positively affected with increased political inclusiveness (Model 15). This also holds when I control for political regime type. Hence, the results in Table 3 partly support Hypothesis 3, which stated that the conflict potential of HIs actually increases with more inclusive electoral systems.

\subsection{Socioeconomic $\mathrm{HI}$ and Political Exclusion - A Dangerous Mix?}

Finally, I set out to test whether the simultaneous presence of socioeconomic horizontal inequalities between the masses and political exclusion (implying horizontal inequalities among the elites) can be especially explosive. In Table 4 I include interaction terms between the two kinds of inter-regional horizontal inequality in order to investigate whether the effect of socioeconomic horizontal inequalities increases with higher levels of political exclusion of minority group elites.

Table 4 reveals that the term for political exclusion never has a separate significant effect, and the sign is even negative. However, the variable has a very strong impact on the relationship between inter-regional asset inequality and conflict, as demonstrated in by the interaction term regional asset $\mathrm{HI}$ and political exclusion in Model 18. This relationship is graphed in Figure 4.

The figure shows that the effect of regional asset HI is positive for all levels of political exclusion, but drastically increases with severe political exclusion. The peak for the two curves is extremely high - indicating that the risk of a conflict onset in a given year is close to $24 \%$.

However few observations are found within this range of the variables. An example is Burundi in the $90 \mathrm{~s}$, with the values 2.55 on political exclusion and 0.74 on inter-regional asset inequality.

\footnotetext{
${ }^{22}$ I also ran all the subsequent models including the term for proximity to transition. The term turned out positive and significant in all models, but the other regression results did not change substantively (results not shown here).
} 
The interaction term for political exclusion and regional educational HI (Model 20) is also strongly positive, but not significantly so. In sum, Table 4 provides some empirical support for Hypothesis 4. However, it should be noted that the measure for political exclusion is rather crude. It could be worth retesting the hypothesis with disaggregated data at the sub-national level.

\section{Concluding Remarks}

This paper represents a first effort at systematically measuring the impact of the political environment on the relationship between socioeconomic horizontal inequalities and civil conflict onset. The main finding is that socioeconomic horizontal inequalities seem to be positively related with conflict for all the three kinds of group identifiers suggested here (ethnic, religious and regional groups). Furthermore the relationship between regional (educational) HIs and conflict seems to be affected by regime type and electoral system, as well as the level of political exclusion in society. In fact horizontal inequalities seem to be particularly conflict provoking in democratic regimes with inclusive electoral systems. This is of course not to say that democracy and/or political inclusiveness as such breed conflict, but that countries with sharp socioeconomic HIs despite democratic rule and a seemingly politically inclusive system may be particularly at risk for conflict. Furthermore, I find a strong interaction effect between regional asset HI and the level of de facto political exclusion of certain minorities. In sum, these results provide some support to all the Hypotheses 1-4, but the estimates are sensitive to what indicator of inequality is used. Sometimes it is the household asset indicator which shows a significant effect, and other times it is the education indicator. These two indicators of social wellbeing are quite interrelated both in theory and statistical correlation, so it would be risky to speculate too much about their potentially different effects.

Despite some interesting findings, several factors call for caution when interpreting the results reported here. First, the sample is limited to developing countries which have hosted DHS-surveys in the period 1986-2003, which calls into question the degree to which the results can be generalized. Also, within this sample the intra- and extrapolations of inequality values could be problematic. However, this should not be too huge a problem, since horizontal inequalities seem to remain quite stable over time, as noted above. ${ }^{23}$

Second, there is always a potential problem for producing misleading findings due to poor operationalizations of certain variables. Generating summary measures of horizontal inequalities at the national level is a challenging task. There is a need to define the relevant groups, calculate their respective mean welfare scores, and then measuring inequalities based on these scores. Most empirical work on group differences, including the tests presented here, uses simple measures of differences in performance between the major groups in society, aggregating these for cross-country comparisons. The advantage of such an approach is that the measure is very simple and intuitively makes sense. However, it is potentially problematic since it may ignore certain politically relevant groups in society (see e.g. Stewart, Brown \& Mancini, 2005).

\footnotetext{
${ }^{23}$ Even so, I reran all the models without allowing for any backward extrapolation of the inequality values. Most of the results remained similar, but some effects dropped below significance (results not reported here). This procedure radically decreases the sample to less than half and the number of conflicts drops to very low figures in many of the models.
} 
Following e.g. Mancini (2005: 9) I reran all the models with an alternative measure of horizontal inequalities, the group-based coefficient of variation $(\mathrm{GCOV})^{24}$, weighted by group size for all the groups consisting of more than $1 \%$ of the population in each country (results not reported here). Most of the effects remained quite similar, but dropped below significance in many models. It is hard to say whether this means that horizontal inequalities may be less important than suggested here, or if it is just signaling that HIs are extremely complex phenomena and very sensitive to different measurement techniques. The implication of the latter seems to be that whenever possible, horizontal inequalities should be measured and analyzed at the subnational level. A handful of quantitative case studies of particular countries have done exactly this (see e.g. Mancini, 2005; Murshed \& Gates, 2005; Tadjoeddin, 2003), but this of course requires disaggregation of the dependent variable and preferably the other independent variables (see also Østby, Nordås \& Rød (2006) for a preliminary disaggregated analysis of inter- and intra-regional inequalities and civil conflict in 21 African countries). Despite the advantage of disaggregated studies of conflict, political variables such as regime type and electoral system (which are important indicators in this paper) are by definition country-level variables. Testing the combined effects of subnational and national variables could be carried out in a multilevel model, (see e.g. Goldstein, 1995).

The search for the underlying causes of civil wars is an on-going one, and few definitive answers can be expected. Yet, because of the heavy costs and human suffering that are continuously imposed by on-going civil conflicts, it is important to take some action on the basis of our current knowledge. The main policy implication that can be drawn from the results reported in this paper is the importance of addressing horizontal inequalities. Political institutions are not sufficient to ensure peace. The findings of this paper support Stewart \& O'Sullivan's (1998) conclusion drawn from case studies: The combination of two factors seems to be of utmost importance in mitigating conflict: First, the establishment of politically inclusive government which incorporates representatives from all the major identity groups at the political level, and second, the realization of a social system which widely spreads the benefits of progress, providing socioeconomic growth among all the significant regional, religious and ethnic groups in society. In other words, what seems to be required in order to ensure peace in developing countries is the combination of politically and economically inclusive government.

\footnotetext{
${ }^{24}$ Note that the weighted group coefficient of variation had already been proposed thirty years ago, by Williamson (1965: 11).
} 


\section{References}

Achen, Christopher H., 2002. 'Toward a New Political Methodology: Microfoundations and ART', Annual Review of Political Science 5: 423-450.

Aydin, Aysegul \& Scott Gates, 2005. 'Rulers as Mass Murderers: Political Institutions and Human Insecurity', paper presented at the Conference, "Hastening the Day: When Peace Enforcers Can Leave?

Understanding Security in the 21st Century Civil Conflicts", McGill University and Université de Montréal, Montreal, Canada, 1-2 April.

Beck, Nathaniel; Jonathan N. Katz \& Richard Tucker, 1998. 'Taking Time Seriously: Time-Series-CrossSection Analysis with a Binary Dependent Variable', American Journal of Political Science 42(4): $1260-1288$.

Binningsbø, Helga Malmin, 2005. 'Consociational Democracy and Postconflict Peace: Will Power-Sharing Institutions Increase the Probability of lasting peace After Civil War?', paper presented at the 13th National Conference in Political Science. Hurdalsjøen, 5-7 January.

Brown, Graham, 2005. 'Horizontal Inequality or Polarization? Inter-group Economic Disparity and its Relationship with Conflict'. Paper presented at the IGCC conference Disaggregating the Study of Civil War and Transnational Violence. San Diego, CA, 7-8 March.

Buhaug, Halvard \& Scott Gates, 2002. 'The Geography of Civil War', Journal of Peace Research 39(4): 417433.

CIA, annual. The World Factbook. Washington, DC: Central Intelligence Agency.

Collier, Paul \& Anke Hoeffler, 2004. 'Greed and Grievance in Civil War', Oxford Economic Papers 56(4): $563-595$.

Davenport, Christian, 2003. Minorities at Risk: Dataset Users Manual. CIDCM, University of Maryland.

Davies, James C., 1962. ‘Towards a Theory of Revolution’, American Sociological Review 27(1): 5-19.

Ellingsen, Tanja, 2000. 'Colorful Community or Ethnic Witches' Brew? Multiethnicity and Domestic Conflict During and After the Cold War', Journal of Conflict Resolution 44(2): 228-249.

Fearon, James D. \& David D. Laitin, 2003. 'Ethnicity, Insurgency, and Civil War', American Political Science Review 97(1): 75-90.

Gates, Scott, Håvard Hegre, Mark P. Jones \& Håvard Strand, 2006. 'Institutional Inconsistency and Political Instability: The Duration of Polities', American Journal of Political Science 50(4): 893-908.

Gleditsch, Nils Petter, Peter Wallensteen, Mikael Eriksson, Margareta Sollenberg \& Håvard Strand, 2002. 'Armed Conflict 1946-2001: A New Dataset', Journal of Peace Research 39(5): 615-637.

Golder, Matt, 2005. 'Democratic Electoral Systems Around the World, 1946-2000', Electoral Studies 24(1): $103-121$.

Goldstein, Harvey. 1995. Multilevel Statistical Models. New York: Halstead Press.

Goldstone, Jack A., 2001. 'Demography, Environment, and Security', in Paul F. Diehl \& Nils Petter Gleditsch, eds, Environmental Conflict. Boulder, CO: Westview (84-108). 
Gurr, Ted Robert, 2000. Peoples Versus States. Minorities at Risk in the New Century. Washington, DC: United States Institute of Peace Press.

Hegre, Håvard, Tanja Ellingsen, Scott Gates \& Nils Petter Gleditsch, 2001. 'Toward a Democratic Civil Peace? Democracy, Political Change, and Civil War, 1816-1992', American Political Science Review 95(1): 17-33.

Hegre, Håvard \& Nicholas Sambanis, 2005. Sensitivity Analysis of the Empirical Literature on Civil War

Onset. Paper presented at the 46th Annual ISA Convention. Honolulu, HI, 1-5 March.

Horowitz, Donald L., 2000. Ethnic Groups in Conflict. 2nd edn. ed. Los Angeles, CA: University of California Press. [Originally published in 1985].

Jaggers, Keith \& Ted Robert Gurr, 1995. 'Tracking Democracy's Third Wave with the Polity III Data', Journal of Peace Research 32(4): 469-482.

Kanbur, Ravi \& Anthony J. Venables, (eds) 2005. Spatial Inequality and Development. Oxford: Oxford University Press.

Langer, Arnim, 2005. 'Horizontal Inequalities and Violent Group Mobilization in Côte d'Ivoire', Oxford Development Studies 33(2): 25-45.

Lijhart, Arend, 1999. Patterns of Democracy: Government Forms and Performance in Thirty-Six Countries. New Haven \& London: Yale University Press.

Marshall, Monty G \& Keith Jaggers, 2003. Polity IV Project: Political Regime Characteristics and Transitions, 1800-2001. University of Maryland, MD: CIDCM.

Mancini, Luca, 2005. 'Horizontal Inequality and Communal Violence: Evidence from Indonesian Districts', CRISE Working Paper No. 22.

Minority Rights Group International, ed., 1997. World Directory of Minorities. London: MRG.

Murshed, S. Mansoob \& Scott Gates, 2005. 'Spatial-Horizontal Inequality and the Maoist Insurgency in Nepal', Review of Development Economics 9(1): 121-134.

Neumayer, Eric, 2003. 'Good Policy Can Lower Violent Crime: Evidence from a Cross-National Panel of Homicide Rates, 1980-97', Journal of Peace Research 40(6): 619-640.

Olson, Mancur, 1965. The Logic of Collective Action. Cambridge, MA: Harvard University Press.

Østby, Gudrun, 2005a. 'Horizontal Inequalities and Civil Conflict', paper presented at the 46th Annual ISA Convention, Honolulu, HI, 1-5 March.

Østby, Gudrun, 2005b. 'Dissaggregated Inequalities and Conflict in Developing Countries', paper presented at the Polarization and Conflict (PAC) Summer Meeting. Konstanz, 2-5 June.

Østby, Gudrun; Ragnhild Nordås \& Jan Ketil Rød, 2006. 'Regional Inequalities and Civil Conflict in 21 SubSaharan African Countries, 1986-2004', paper presented at the $47^{\text {th }}$ Annual Convention of the International Studies Association, San Diego, CA, USA, 22-25 March.

Posner, Daniel N., 2004. 'The Political Salience of Cultural Difference: Why Chewas and Tumbukas are Allies in Zambia and Adversaries in Malawi', American Political Science Review 98(4): 529-545. 
Reynal-Querol, Marta, 2002a. 'Ethnicity, Political Systems, and Civil Wars', Journal of Conflict Resolution 46(1): 29-54.

Reynal-Querol, Marta, 2002b. 'Political Systems, Stability and Civil Wars', Defence and Peace Economics 13(6): 465-483.

Rogowski, Ronald \& Duncan C. MacRae, 2004. Inequality and Institutions: What Theory, History and (Some) Data Tell Us. Paper presented at the APSA Conference. Chicago, IL, 2-5 September.

Rothchild, Donald, 1983. 'Collective demands for improved distributions', in Donald Rothchild \& Victor A. Olorunsola, eds, State Versus Ethnic Claims: African Policy Dilemmas. Boulder, CO: West View Press (172-198).

Rutstein, Shea Oscar \& Guillermo Rojas, 2003. Guide to DHS Statistics. Calverton, Maryland: Demographic and Health Surveys, ORC Macro.

Sigelman, Lee \& Miles Simpson, 1977. ‘A Cross-National Test of the Linkage Between Economic Inequality and Political Violence', Journal of Conflict Resolution 21(1): 105-128.

StataCorp., 2003. Stata Statistical Software: Release 8.2 (1) (User's Guide). College Station, TX: Stata Corporation.

Stewart, Frances; Graham Brown \& Luca Mancini, 2005. 'Why Horizontal Inequalities Matter: Some Implications for Measurement', University of Oxford, CRISE Working paper No. 19.

Stewart, Frances \& Meghan O’Sullivan, 1998. 'Democracy, Conflict and Development - Three Cases', Queen Elizabeth House Working Paper Number 15.

Stewart, Frances, 2000. 'Crisis Prevention: Tackling Horizontal Inequalities', Oxford Development Studies 28(3): 245-262.

Stewart, Frances, 2002. 'Horizontal Inequalities: A Neglected Dimension of Development', Queen Elizabeth House Working Paper Number 81.

Strand, Håvard \& Henrik Urdal, 2005. Differential Growth, Political Instability and Violent Conflict. Paper presented at the 46th Annual ISA Convention. Honolulu, HI, 1-5 March.

Tadjoeddin, Mohammad Zulfan, 2003. 'Aspiration to Inequality: Regional Disparity and Centre-Regional Conflicts in Indonesia', paper presented at the UNI/WIDER Project Conference on Spatial Inequality in Asia, Tokyo, Japan, 28-29 March.

Tomz, Michael; Jason Wittenberg \& Gary King, 2003. CLARIFY: Software for Interpreting and Presenting Statistical Results. Stanford University, University of Wisconsin, and Harvard University.

Van den Berghe, Pierre, 2002. 'Mulitcultural Democracy: Can It Work? Nations and Nationalism 8(4): 433449.

Vanhanen, Tatu, 2000. 'A New Dataset for Measuring Democracy, 1810-1998', Journal of Peace Research 37(2): 251-265. [Data available at http://www.prio.no/jpr/datasets.asp].

Wilkinson, Steven I, 2004. Votes and Violence: Electoral Competition and Ethnic Riots in India. Cambridge: Cambridge University Press. 
Williamson, Jeffrey G., 1965. "Regional Inequality and the Process of National Development: A Description of the Patterns". Economic Development and Cultural Change 13(4): 1-84

World Bank, 2004. World Development Indicators 2004. Washington, DC: Development Data Center, International Bank for Reconstruction and Development.

World Bank, 2006. World Development Report 2006: Equity and Development. New York: World Bank. 
Table 1. Logit Regression of Civil War Onset and HIs, 1986-2003

\begin{tabular}{|c|c|c|c|c|c|c|}
\hline & $\begin{array}{l}\text { Model } 1 \\
\text { (Ethnic gr.) }\end{array}$ & $\begin{array}{l}\text { Model } 2 \\
\text { (Ethnic gr.) }\end{array}$ & $\begin{array}{l}\text { Model } 3 \\
\text { (Rel. gr.) }\end{array}$ & $\begin{array}{l}\text { Model } 4 \\
\text { (Rel gr.) }\end{array}$ & $\begin{array}{l}\text { Model } 5 \\
\text { (Regions) }\end{array}$ & $\begin{array}{l}\text { Model } 6 \\
\text { (Regions) }\end{array}$ \\
\hline HI_Asset (Ethnic gr.) & $\begin{array}{l}3.39^{*} \\
(1.82)\end{array}$ & & & & & \\
\hline HI_Educ. (Ethnic gr.) & & $\begin{array}{l}1.96^{* *} \\
(2.02)\end{array}$ & & & & \\
\hline HI_Asset (Religious gr.) & & & $\begin{array}{l}3.67 * * \\
(2.52)\end{array}$ & & & \\
\hline HI_Educ. (Religious gr.) & & & & $\begin{array}{l}1.84 * * \\
(2.51)\end{array}$ & & \\
\hline HI_Asset (Regions) & & & & & $\begin{array}{l}2.70^{* * *} \\
-3.15\end{array}$ & \\
\hline HI_Educ. (Regions) & & & & & & $\begin{array}{l}2.18^{* * *} \\
-3.04\end{array}$ \\
\hline Population (ln) & $\begin{array}{l}-0.59^{*} \\
(-1.74)\end{array}$ & $\begin{array}{l}-0.46 \\
(-1.50)\end{array}$ & $\begin{array}{l}0.053 \\
(0.18)\end{array}$ & $\begin{array}{l}0.13 \\
(0.43)\end{array}$ & $\begin{array}{l}0.22 \\
(-0.78)\end{array}$ & $\begin{array}{l}0.17 \\
(-0.63)\end{array}$ \\
\hline GDP per capita $(\ln )_{t-1}$ & $\begin{array}{l}-0.81 * * \\
(-2.27)\end{array}$ & $\begin{array}{l}-0.67^{*} \\
(-1.83)\end{array}$ & $\begin{array}{l}0.14 \\
(0.41)\end{array}$ & $\begin{array}{l}0.28 \\
(0.78)\end{array}$ & $\begin{array}{l}0.027 \\
(0.1)\end{array}$ & $\begin{array}{l}0.051 \\
(0.2)\end{array}$ \\
\hline Peaceyears & $\begin{array}{l}0.42 \\
(1.10)\end{array}$ & $\begin{array}{l}0.39 \\
(1.15)\end{array}$ & $\begin{array}{l}-0.012 \\
(-0.05)\end{array}$ & $\begin{array}{l}0.0057 \\
(0.02)\end{array}$ & $\begin{array}{l}-0.069 \\
(-0.37)\end{array}$ & $\begin{array}{l}-0.11 \\
(-0.58)\end{array}$ \\
\hline Constant & $\begin{array}{l}11.33^{*} \\
(1.71)\end{array}$ & $\begin{array}{l}8.37 \\
(1.32)\end{array}$ & $\begin{array}{l}-4.82 \\
(-0.74)\end{array}$ & $\begin{array}{l}-7.11 \\
(-1.04)\end{array}$ & $\begin{array}{l}-7.26 \\
(-1.25)\end{array}$ & $\begin{array}{l}-6.37 \\
(-1.21)\end{array}$ \\
\hline LL & -73.57 & -73.69 & -93.39 & -93.34 & -136.88 & -137.13 \\
\hline Pseudo $\mathrm{R}^{2}$ & 0.112 & 0.110 & 0.088 & 0.089 & 0.061 & 0.059 \\
\hline \# Conflicts & 20 & 20 & 25 & 25 & 36 & 36 \\
\hline \# Countries & 35 & 35 & 41 & 41 & 55 & 55 \\
\hline $\mathrm{N}$ & 473 & 473 & 566 & 566 & 777 & 777 \\
\hline
\end{tabular}

Note: Logit regression coefficients, $\mathrm{z}$-values are in parentheses. Estimates for three natural cubic splines not shown in table. ${ }^{*} \mathrm{p}<0.10 ; * * \mathrm{p} \leq 0.05 ; * * \mathrm{p} \leq 0.01$. 
Table 2. Logit regression of civil war onset, HIs and regime type, 1986-2003

\begin{tabular}{|c|c|c|c|c|c|c|}
\hline & Model 7 & Model 8 & Model 9 & Model 10 & Model 11 & Model 12 \\
\hline HI_Asset (Regions) & $\begin{array}{l}3.11 * * \\
(2.35)\end{array}$ & & & & & \\
\hline HI_Educ. (Regions) & & $\begin{array}{l}2.046^{* * *} \\
(2.98)\end{array}$ & $\begin{array}{l}2.50 * * * \\
(2.82)\end{array}$ & $\begin{array}{l}2.59 * * * \\
(2.82)\end{array}$ & $\begin{array}{l}2.64 * * * \\
(3.19)\end{array}$ & $\begin{array}{l}2.89 * * * \\
(2.84)\end{array}$ \\
\hline $\begin{array}{l}\text { Semidemocracy t-1 } \\
\quad \text { (ref.c.: Democracy) }\end{array}$ & $\begin{array}{l}0.79 \\
(1.34)\end{array}$ & $\begin{array}{l}0.67 \\
(1.28)\end{array}$ & $\begin{array}{l}0.89 \\
(1.46)\end{array}$ & $\begin{array}{l}0.66 \\
(1.13)\end{array}$ & & \\
\hline $\begin{array}{l}\text { Autocracy }{ }_{\mathrm{t}-1} \\
\quad \text { (ref.c.: Democracy) }\end{array}$ & $\begin{array}{l}0.65 \\
(0.94)\end{array}$ & $\begin{array}{l}0.73 \\
(1.20)\end{array}$ & $\begin{array}{l}1.07 \\
(1.63)\end{array}$ & $\begin{array}{l}1.01 \\
(1.53)\end{array}$ & & \\
\hline HI_Asset*Semi-Dem & $\begin{array}{l}-1.36 \\
(-0.43)\end{array}$ & & & & & \\
\hline HI_Asset*Autocracy & $\begin{array}{l}-0.89 \\
(-0.27)\end{array}$ & & & & & \\
\hline HI_Educ.*Semi-Dem & & & $\begin{array}{l}-2.53 \\
(-1.31)\end{array}$ & $\begin{array}{l}-1.89 \\
(-1.04)\end{array}$ & & \\
\hline HI_Educ.*Autocracy & & & $\begin{array}{l}-4.11 * * \\
(-1.99)\end{array}$ & $\begin{array}{l}-4.56^{* *} \\
(-2.06)\end{array}$ & & \\
\hline Polity $t-1$ & & & & & $\begin{array}{l}-0.038 \\
(-1.06)\end{array}$ & \\
\hline HI_Educ. ${ }^{\text {Polity }}$ & & & & & $\begin{array}{l}0.27 * * \\
(2.47)\end{array}$ & \\
\hline $\operatorname{SIP}_{t-1}$ & & & & & & $\begin{array}{l}-1.25 \\
(-1.44)\end{array}$ \\
\hline HI_Educ.*SIP & & & & & & $\begin{array}{l}6.70^{* *} \\
(2.26)\end{array}$ \\
\hline Proximity of Transition & & & & $\begin{array}{l}1.45^{* * *} \\
(3.30)\end{array}$ & & \\
\hline Population (ln) & $\begin{array}{l}0.26 \\
(0.83)\end{array}$ & $\begin{array}{l}0.16 \\
(0.62)\end{array}$ & $\begin{array}{l}0.14 \\
(0.52)\end{array}$ & $\begin{array}{l}0.20 \\
(0.81)\end{array}$ & $\begin{array}{l}0.17 \\
(0.63)\end{array}$ & $\begin{array}{l}0.21 \\
(0.73)\end{array}$ \\
\hline GDP per capita $(\ln )_{t-1}$ & $\begin{array}{l}0.044 \\
(0.16)\end{array}$ & $\begin{array}{l}0.037 \\
(0.14)\end{array}$ & $\begin{array}{l}0.19 \\
(0.69)\end{array}$ & $\begin{array}{l}0.23 \\
(0.86)\end{array}$ & $\begin{array}{l}0.20 \\
(0.71)\end{array}$ & $\begin{array}{l}0.29 \\
(0.96)\end{array}$ \\
\hline Peaceyears & $\begin{array}{l}-0.068 \\
(-0.37)\end{array}$ & $\begin{array}{l}-0.11 \\
(-0.62)\end{array}$ & $\begin{array}{l}-0.14 \\
(-0.79)\end{array}$ & $\begin{array}{l}-0.060 \\
(-0.35)\end{array}$ & $\begin{array}{l}-0.15 \\
(-0.89)\end{array}$ & $\begin{array}{l}-0.044 \\
(-0.24)\end{array}$ \\
\hline Constant & $\begin{array}{l}-7.075 \\
(-1.22) \\
\end{array}$ & $\begin{array}{l}-6.54 \\
(-1.30) \\
\end{array}$ & $\begin{array}{l}-6.24 \\
(-1.27) \\
\end{array}$ & $\begin{array}{l}-8.14^{*} \\
(-1.76)\end{array}$ & $\begin{array}{l}-6.80 \\
(-1.26) \\
\end{array}$ & $\begin{array}{l}-8.20 \\
(-1.44)\end{array}$ \\
\hline $\mathrm{LL}$ & -130.63 & -131.56 & -129.59 & -125.10 & -130.34 & -113.85 \\
\hline Pseudo $\mathrm{R}^{2}$ & 0.077 & 0.070 & 0.084 & 0.116 & 0.079 & 0.085 \\
\hline \# Conflicts & 35 & 35 & 35 & 35 & 35 & 31 \\
\hline \# Countries & 55 & 55 & 55 & 55 & 55 & 53 \\
\hline $\mathrm{N}$ & 752 & 752 & 752 & 752 & 752 & 648 \\
\hline
\end{tabular}

Note: Logit regression coefficients, $\mathrm{z}$-values are in parentheses. Estimates for three natural cubic splines not shown in table. ${ }^{*} \mathrm{p}<0.10 ; * * \mathrm{p} \leq 0.05 ; * * * \mathrm{p} \leq 0.01$. 
Table 3. Logit Regression of Civil War Onset, HIs and Electoral Systems, 1986-2003

\begin{tabular}{|c|c|c|c|c|}
\hline & Model 13 & Model 14 & Model 15 & Model 16 \\
\hline HI_Asset (Regions) & $\begin{array}{l}3.34 * * \\
(2.43)\end{array}$ & & & \\
\hline HI_Educ. (Regions) & & $\begin{array}{l}1.99 * * \\
(2.51)\end{array}$ & $\begin{array}{l}2.90 * * * \\
(2.78)\end{array}$ & $\begin{array}{l}2.98 * * * \\
(3.13)\end{array}$ \\
\hline Inclusive Electoral Syst. (IES) $t-1$ & $\begin{array}{l}-0.51 \\
(-1.58)\end{array}$ & $\begin{array}{l}-0.46 \\
(-1.27)\end{array}$ & $\begin{array}{l}-0.75^{* *} \\
(-2.02)\end{array}$ & $\begin{array}{l}-1.30 * * * \\
(-2.72)\end{array}$ \\
\hline HI_Asset*IES & $\begin{array}{l}1.403 \\
(0.81)\end{array}$ & & & \\
\hline HI_Educ*IES & & & $\begin{array}{l}2.68 * \\
(1.85)\end{array}$ & $\begin{array}{l}2.78 * \\
(1.72)\end{array}$ \\
\hline Polity $t-1$ & & & & $\begin{array}{l}0.066 \\
(1.25)\end{array}$ \\
\hline Polity $2 t-1$ & & & & $\begin{array}{l}0.0091 \\
(1.19)\end{array}$ \\
\hline Population (ln) & $\begin{array}{l}0.21 \\
(0.67)\end{array}$ & $\begin{array}{l}0.12 \\
(0.43)\end{array}$ & $\begin{array}{l}0.12 \\
(0.42)\end{array}$ & $\begin{array}{l}0.12 \\
(0.40)\end{array}$ \\
\hline GDP per capita $(\ln )_{t-1}$ & $\begin{array}{l}0.18 \\
(0.65)\end{array}$ & $\begin{array}{l}0.10 \\
(0.40)\end{array}$ & $\begin{array}{l}0.18 \\
(0.70)\end{array}$ & $\begin{array}{l}0.12 \\
(0.44)\end{array}$ \\
\hline Peaceyears & $\begin{array}{l}0.021 \\
(0.11)\end{array}$ & $\begin{array}{l}-0.0091 \\
(-0.05)\end{array}$ & $\begin{array}{l}-0.017 \\
(-0.09)\end{array}$ & $\begin{array}{l}-0.056 \\
(-0.31)\end{array}$ \\
\hline Constant & $\begin{array}{l}-7.50 \\
(-1.22) \\
\end{array}$ & $\begin{array}{l}-5.67 \\
(-1.05) \\
\end{array}$ & $\begin{array}{l}-6.035 \\
(-1.12) \\
\end{array}$ & $\begin{array}{l}-5.90 \\
(-1.08) \\
\end{array}$ \\
\hline LL & -120.58 & -122.31 & -120.10 & -114.91 \\
\hline Pseudo $\mathrm{R}^{2}$ & 0.080 & 0.067 & 0.084 & 0.096 \\
\hline \# Conflicts & 33 & 33 & 33 & 32 \\
\hline \# Countries & 53 & 53 & 53 & 53 \\
\hline $\mathrm{N}$ & 661 & 661 & 661 & 640 \\
\hline
\end{tabular}

Note: Logit regression coefficients, z-values are in parentheses. Estimates for three natural cubic splines not shown in table. ${ }^{*} \mathrm{p}<0.10 ; * * \mathrm{p} \leq 0.05 ; * * * \mathrm{p} \leq 0.01$. 
Table 4. Logit Regression of Civil War Onset, HIs and Political Exclusion, 1986-2003

\begin{tabular}{|c|c|c|c|c|}
\hline & Model 17 & Model 18 & Model 19 & Model 20 \\
\hline HI_Asset (Regions) & $\begin{array}{l}3.78^{* *} \\
(2.19)\end{array}$ & $\begin{array}{l}4.37 * * \\
(2.08)\end{array}$ & & \\
\hline HI_Educ. (Regions) & & & $\begin{array}{l}2.75^{* *} \\
(2.54)\end{array}$ & $\begin{array}{l}2.91 * * \\
(2.27)\end{array}$ \\
\hline Political Exclusion $t-1$ & $\begin{array}{l}-0.088 \\
(-0.24)\end{array}$ & $\begin{array}{l}-0.79 \\
(-1.59)\end{array}$ & $\begin{array}{l}-.050 \\
(-0.11)\end{array}$ & $\begin{array}{l}-0.53 \\
(-0.72)\end{array}$ \\
\hline HI_Asset*Pol_Excl & & $\begin{array}{l}3.50 * * * \\
(2.59)\end{array}$ & & \\
\hline HI_Educ*Pol_Excl & & & & $\begin{array}{l}2.48 \\
(1.51)\end{array}$ \\
\hline Population (ln) & $\begin{array}{l}0.59 \\
(1.56)\end{array}$ & $\begin{array}{l}0.68 \\
(1.95)\end{array}$ & $\begin{array}{l}0.436 \\
(1.34)\end{array}$ & $\begin{array}{l}0.48 \\
(1.48)\end{array}$ \\
\hline GDP per capita $(\ln )_{t-1}$ & $\begin{array}{l}0.11 \\
(0.29)\end{array}$ & $\begin{array}{l}0.12 \\
(0.29)\end{array}$ & $\begin{array}{l}-.027 \\
(-0.08)\end{array}$ & $\begin{array}{l}-0.087 \\
(-0.28)\end{array}$ \\
\hline Peaceyears & $\begin{array}{l}0.083 \\
(0.43)\end{array}$ & $\begin{array}{l}0.15 \\
(0.73)\end{array}$ & $\begin{array}{l}.032 \\
(0.14)\end{array}$ & $\begin{array}{l}0.083 \\
(0.38)\end{array}$ \\
\hline Constant & $\begin{array}{l}-14.56^{*} \\
(-1.79) \\
\end{array}$ & $\begin{array}{l}-15.20^{* *} \\
(-2.12)\end{array}$ & $\begin{array}{l}-10.63 \\
(-1.60) \\
\end{array}$ & $\begin{array}{l}-10.03 \\
(-1.61) \\
\end{array}$ \\
\hline LL & -88.87 & -86.38 & -88.78 & -87.24 \\
\hline Pseudo $\mathrm{R}^{2}$ & 0.098 & 0.123 & 0.099 & 0.114 \\
\hline \# Conflicts & 24 & 24 & 24 & 24 \\
\hline \# Countries & 41 & 41 & 41 & 41 \\
\hline $\mathrm{N}$ & 547 & 547 & 547 & 547 \\
\hline
\end{tabular}


Figure 1. Regional HIs in Peru, Various Years.

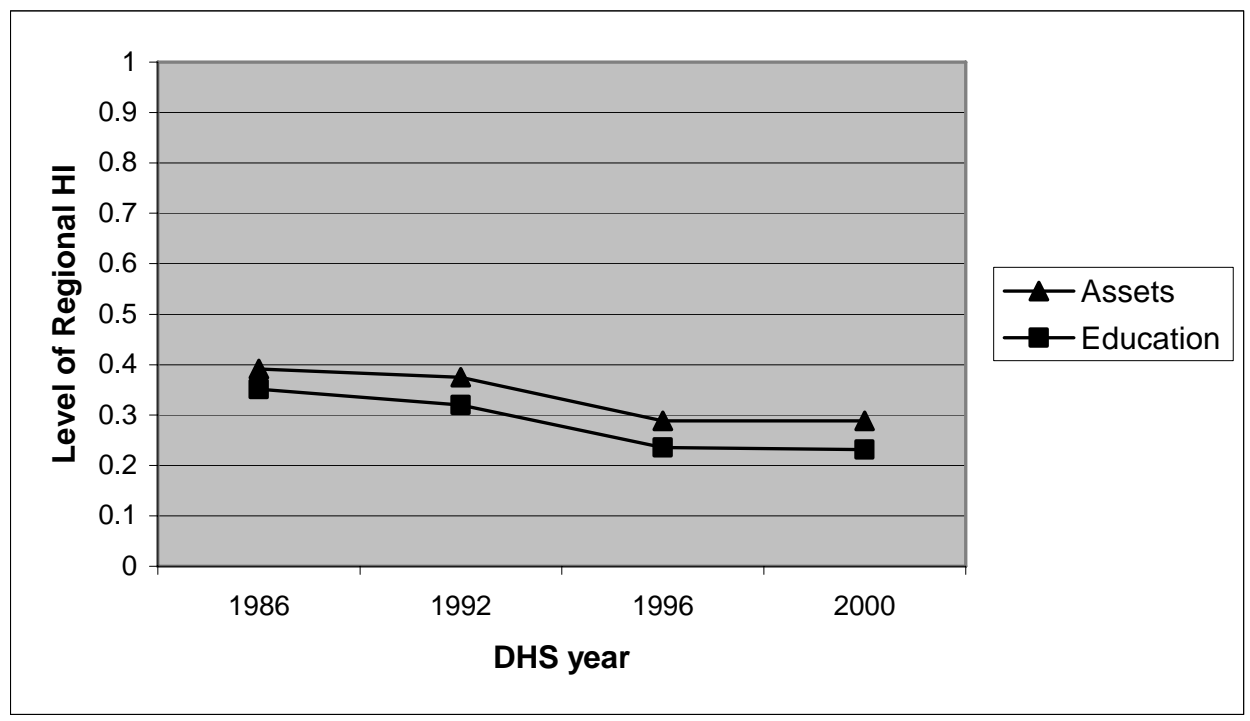

Figure 2. Regional HIs in Zimbabwe, Various Years.

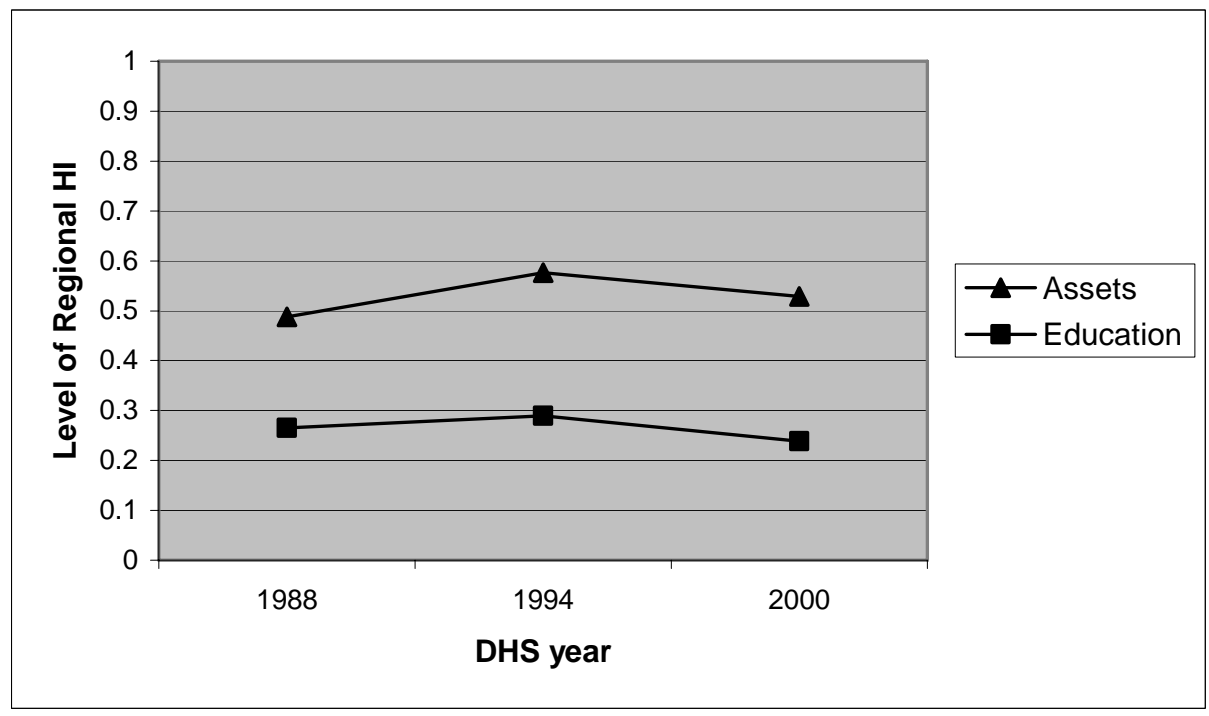


Figure 3. Horizontal Inequality and Conflict Risk by Regime Type (POLITY IV), Developing Countries, 1986-2003.

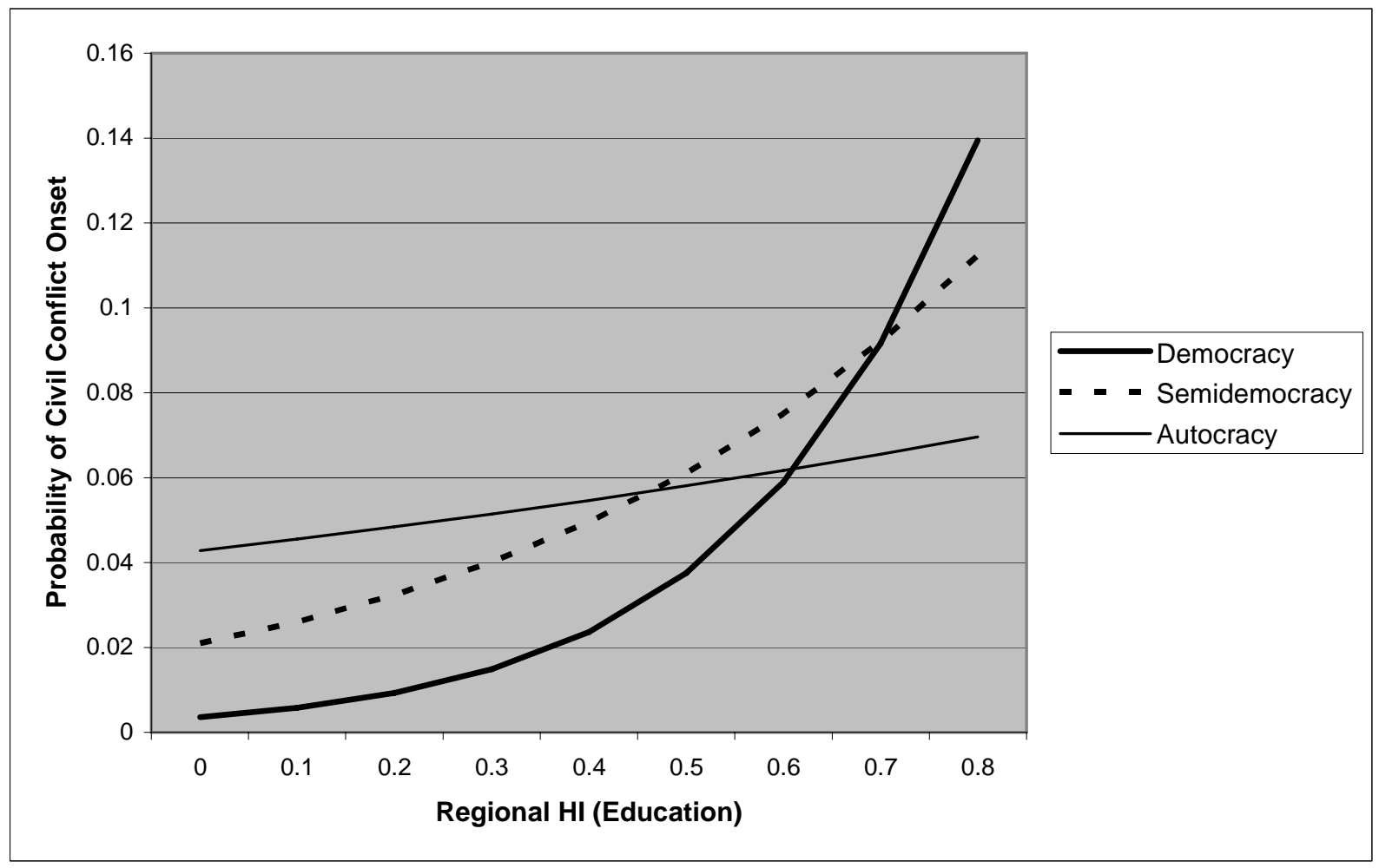

Note: Figure 3 is generated on the basis of Model 9 in Table 2.

Figure 4. Regional HIs (Assets) and Political Exclusion, Developing Countries, 19862003.

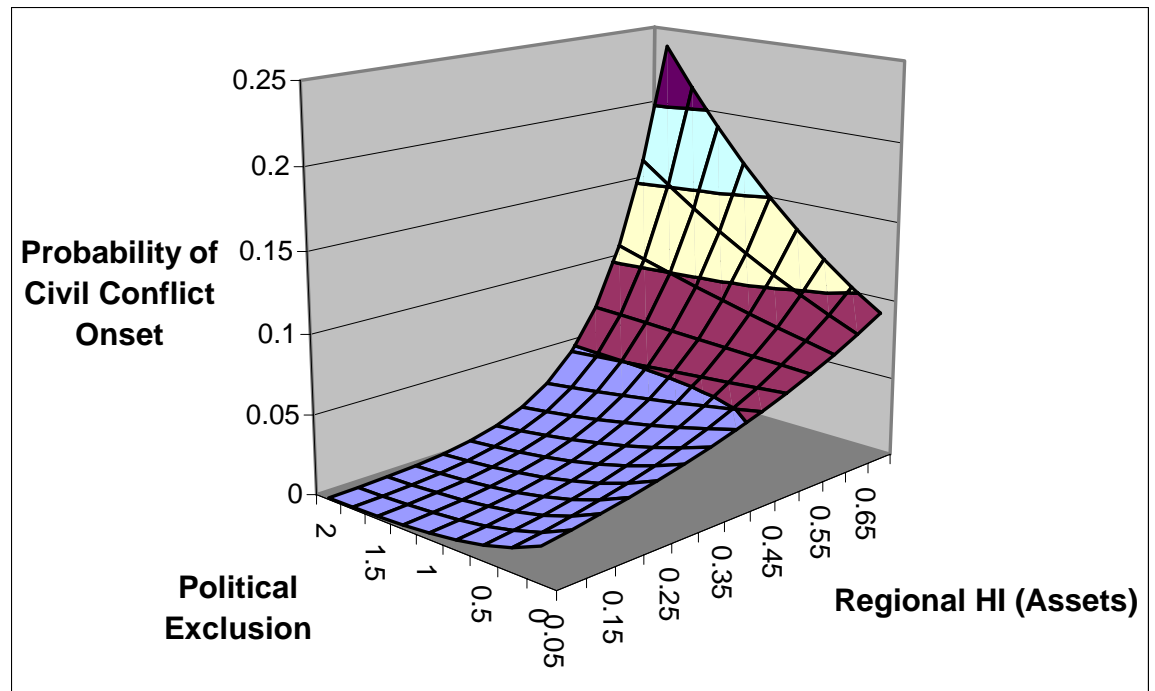

Note: Figure 4 is generated on the basis of Model 18 in Table 4. 


\section{Appendix}

Table A1. Summary Statistics of Variables Used in Tables 1-4.

\begin{tabular}{|c|c|c|c|c|c|}
\hline Variable & $\mathrm{N}$ & Mean & Std. Dev. & Min & Max \\
\hline Conflict Onset & 806 & 0.048 & 0.215 & 0 & 1 \\
\hline HI_Asset (Ethnic gr.) & 702 & 0.238 & 0.174 & 0.004 & 0.710 \\
\hline HI_Educ. (Ethnic gr.) & 702 & 0.331 & 0.251 & 0.002 & 0.875 \\
\hline HI_Asset (Religious gr.) & 828 & 0.148 & 0.120 & 0.002 & 0.490 \\
\hline HI_Educ. (Religious gr.) & 828 & 0.259 & 0.235 & 0.000 & 0.858 \\
\hline HI_Asset (Regions) & 1098 & 0.326 & 0.218 & 0.010 & 0.801 \\
\hline HI_Educ (Regions) & 1098 & 0.354 & 0.242 & 0.001 & 0.850 \\
\hline Population (ln) & 1069 & 16.501 & 1.366 & 12.845 & 20.771 \\
\hline GDP per capita $(\ln )_{t-1}$ & 1036 & 7.522 & 0.780 & 6.084 & 9.166 \\
\hline Polity t -1 & 1028 & 0.369 & 6.299 & -9 & 10 \\
\hline Polity2 $t-1$ & 1028 & 39.779 & 24.944 & 0 & 100 \\
\hline Semidemocracy $_{\mathrm{t}-1}$ & 1028 & 0.353 & 0.478 & 0 & 1 \\
\hline Autocracy ${ }_{t-1}$ & 1028 & 0.292 & 0.455 & 0 & 1 \\
\hline $\operatorname{SIP}_{t-1}$ & 893 & 0.460 & 0.349 & 0 & 0.955 \\
\hline Proximity to Transition & 1074 & 0.193 & 0.337 & $2.47 \mathrm{e}-32$ & 1 \\
\hline Inclusive Electoral System $\mathrm{t}_{\mathrm{t}-1}$ & 919 & 0.600 & 0.870 & 0 & 3 \\
\hline Political Exclusion ${ }_{\mathrm{t}-1}$ & 809 & 0.619 & 0.662 & 0 & 3.56 \\
\hline Peaceyears & 1074 & 12.953 & 14.740 & 0 & 57 \\
\hline _spline1 & 1074 & -1678.040 & 2617.469 & -12320 & 0 \\
\hline _spline2 & 1074 & -6179.320 & 10518.610 & -52118 & 0 \\
\hline spline 3 & 1074 & -6858.145 & 12994.400 & -71200 & 0 \\
\hline
\end{tabular}


Table A2. DHS Surveys Used in the Analysis (Country and Survey Year*).

\begin{tabular}{|c|c|c|c|c|}
\hline Country & Year & Country & Year & Country \\
\hline Armenia & 2000 & India & 1992 & Senegal \\
\hline Bangladesh & 1993 & India & 1998 & South Africa \\
\hline Bangladesh & 1996 & Indonesia & 1987 & Sri Lanka (Ceylor \\
\hline Bangladesh & 1999 & Indonesia & 1991 & Sudan \\
\hline Benin & 1996 & Indonesia & 1994 & Tanzania/Tangan! \\
\hline Benin & 2001 & Indonesia & 1997 & Tanzania/Tangan! \\
\hline Bolivia & 1989 & Indonesia & 2002 & Tanzania/Tangan! \\
\hline Bolivia & 1994 & Kazakhstan & 1995 & Thailand \\
\hline Bolivia & 1998 & Kazakhstan & 1999 & Togo \\
\hline Brazil & 1986 & Kenya & 1998 & Togo \\
\hline Brazil & 1991 & Kenya & 2003 & Trinidad and Tob: \\
\hline Brazil & 1996 & Kenya & 1989 & Tunisia \\
\hline Burkina Faso & & & & Turkey/Ottoman \\
\hline (Upper Volta) & 1992 & Kenya & 1993 & Empire \\
\hline Burkina Faso & & Kyrgyz & & Turkey/Ottoman \\
\hline (Upper Volta) & 1998 & Republic & 1997 & Empire \\
\hline $\begin{array}{l}\text { Burkina Faso } \\
\text { (Upper Volta) }\end{array}$ & 2003 & Liberia & 1986 & Uganda \\
\hline Burundi & 1987 & $\begin{array}{l}\text { Madagascar } \\
\text { (Malagasy) }\end{array}$ & 1997 & Uganda \\
\hline Cameroon & 1991 & Malawi & 1992 & Uganda \\
\hline Cameroon & 1998 & Malawi & 2000 & Uzbekistan \\
\hline Central & & & & Vietnam, Democr \\
\hline African Republic & 1994 & Mali & 1987 & Rep. \\
\hline Chad & 1996 & Mali & 1995 & Vietnam, Democr \\
\hline Colombia & 1986 & Mali & 2001 & $\begin{array}{l}\text { Yemen (Arab } \\
\text { Republic of Y.) }\end{array}$ \\
\hline Colombia & 1990 & Mexico & 1987 & Zambia \\
\hline Colombia & 1995 & Morocco & 1987 & Zambia \\
\hline Colombia & 2000 & Morocco & 1992 & Zambia \\
\hline Comoros & 1996 & Mozambique & 1997 & $\begin{array}{l}\text { Zimbabwe } \\
\text { (Rhodesia) }\end{array}$ \\
\hline Cote d'Ivoire & 1998 & Namibia & 1992 & $\begin{array}{l}\text { Zimbabwe } \\
\text { (Rhodesia) }\end{array}$ \\
\hline Cote d'Ivoire & 1994 & Namibia & 2000 & $\begin{array}{l}\text { Zimbabwe } \\
\text { (Rhodesia) }\end{array}$ \\
\hline Dominican & & & & \\
\hline Republic & 1986 & Nepal & 1996 & \\
\hline $\begin{array}{l}\text { Dominican } \\
\text { Republic }\end{array}$ & 1991 & Nepal & 2001 & \\
\hline
\end{tabular}




\begin{tabular}{clll}
$\begin{array}{c}\text { Dominican } \\
\text { Republic } \\
\text { Dominican } \\
\begin{array}{c}\text { Republic } \\
\text { Dominican }\end{array}\end{array}$ & 1996 & Nicaragua & 1997 \\
Republic & 1999 & Nicaragua & 2001 \\
Ecuador & 2002 & Niger & 1992 \\
Egypt & 1987 & Niger & 1998 \\
Egypt & 1992 & Nigeria & 1990 \\
El Salvador & 1995 & Nigeria & 1999 \\
Ethiopia & 1985 & Nigeria & 2003 \\
Gabon & 2000 & Pakistan & 1990 \\
Ghana & 2000 & Paraguay & 1990 \\
Ghana & 1988 & Peru & 1986 \\
Ghana & 1993 & Peru & 1992 \\
Ghana & 1998 & Peru & 1996 \\
Guatemala & 2003 & Peru & 2000 \\
Guatemala & 1987 & Philippines & 1993 \\
Guatemala & 1995 & Philippines & 1998 \\
Guinea & 1998 & Rwanda & 1992 \\
Haiti & 1999 & Rwanda & 2000 \\
Haiti & 1994 & Senegal & 1986 \\
\hline
\end{tabular}

\footnotetext{
* In some countries the survey was conducted over a two year period. In these cases the table reports the first year only.
} 
Table A3. Logit Regression of Civil War Onset, GDP/Capita and Population Size, Various Samples

\begin{tabular}{llll}
\hline & $\begin{array}{l}\text { Model A1 } \\
\text { (Dev. ctrs. only) }\end{array}$ & $\begin{array}{l}\text { Model A2 } \\
\text { (Dev. ctrs. only) }\end{array}$ & $\begin{array}{l}\text { Model A3 } \\
\text { (Global sample) }\end{array}$ \\
\hline HI_Educ. (Regions) & $\begin{array}{l}2.18^{* * *} \\
\text { Population (ln) }\end{array}$ & & \\
& 0.17 & 0.045 & $0.22^{* *}$ \\
GDP per capita (ln) t-1 & -0.63 & $(0.20)$ & $(2.13)$ \\
& 0.051 & -0.29 & $-0.42^{* * *}$ \\
Peaceyears & -0.2 & $(-1.20)$ & $(-3.13)$ \\
& -0.11 & -0.16 & -0.18 \\
Constant & $(-0.58)$ & $(-0.89)$ & $(-1.24)$ \\
& -6.37 & -0.87 & -2.49 \\
\hline LL & $(-1.21)$ & $(-0.20)$ & $(-1.15)$ \\
Pseudo R & -137.13 & -140.73 & -275.48 \\
\# Conflicts & 0.059 & 0.034 & 0.101 \\
\# Countries & 36 & 36 & 69 \\
N & 55 & 55 & 147 \\
\hline Not Logit regra & 777 & 777 & 2186 \\
\hline
\end{tabular}

Note: Logit regression coefficients, z-values are in parentheses. Estimates for three natural cubic splines not shown in table. ${ }^{*} \mathrm{p}<0.10 ; * * \mathrm{p} \leq 0.05 ; * * * \mathrm{p} \leq 0.01$. 